Journal of Engineering and Applied Sciences 14 (Special Issue 6): 9523-9528, 2019

ISSN: 1816-949X

(C) Medwell Journals, 2019

\title{
Determination of Boron Concentrations in Soil Samples of Al-Khlaa and Al-Masharah Areas, Misan Province, Iraq
}

\author{
Zahraa A. Ismail AL-Sudani \\ Department of Physics, College of Science, University of Misan, Amarah, Iraq
}

\begin{abstract}
This study measured boron concentrations in forty soil samples collected from Al-Khlaa and Al-Masharah areas in Maysan Province of Iraq. The samples were analyzed and measured of boron concentrations with using Inductively Coupled Plasma-Optical Emission Spectrometry method (ICP-OES). The results showed that boron concentrations ranged from the $0.71-5.12 \mathrm{ppm}$ with a mean of $2.76 \pm 1.47 \mathrm{ppm}$ for Al-Khlaa area and from $0.32-4.74 \mathrm{ppm}$ with a mean of $1.53 \pm 1.31 \mathrm{ppm}$ for Al-Masharah area. The results indicated that the boron concentrations in these measured soil samples were below the standard value suggested by ATSDR recommended values of $30 \mathrm{ppm}$ for the Earth soil.
\end{abstract}

Key words: Boron, Soil, (ICP-OES), Al-Khlaa, Al-Masharah, Maysan governorate

\section{INTRODUCTION}

Boron is a normally occurring element that is widely distributed in nature with concentrations of about $10 \mathrm{ppm}$ in the planet Earth crust (range: 5 ppm in basalts to $100 \mathrm{ppm}$ in shale), $35 \mathrm{ppm}$ in sandstones, $20 \mathrm{ppm}$ in limestone, $120 \mathrm{ppm}$ in sea vegetation (highest in brownish algae), $50 \mathrm{ppm}$ in land vegetation and about $4.5 \mathrm{ppm}$ in the ocean. Boron occurs in soils at concentrations which range from 10-300 ppm (average $30 \mathrm{ppm}$ ), depending on type of land, amount of organic matter and amount of rainfall (Akram et al., 2004). Boron in the environment is usually found chemically bound to oxygen, usually as alkali or alkaline Earth borates or as boric acidity (ATSDR., 2010; Akram et al., 2011). Boron enters the environment mainly through release into air, drinking water or Earth soil by weathering of stones and volcanic activity. Boron is also released from an thropogenic resources such as essential oil and coal electric power generation plants, fuel wood burning a glass and a glass production manufacturing use of borates/per borates in home and industry, borate mining/handling, leaching of treated cured/timber, consumer products (e.g., make up products, medications, insecticides), sewage/sludge removal and through its use with in agricultural fertilizer, pesticides and copper smelters. It's estimated that the releasing from these resources is significantly less than that from natural weathering procedure (Akram et al., 2004; ATSDR., 2010 and Akram et al., 2011). Boron deficiency is much more common in crops that are grown in soil that have higher amount of free carbonates, low organic matter and high pH. Boric acid, borates and per borates can introduced to environment as these have been used in mild antiseptics, cosmetics, pharmaceuticals (WHO., 2004; Salman and Fleifil, 2015; Fleifi and Salman, 2016). Boron gets into human body mainly from fruits, vegetables and normal water. Occupational exposures from dust particles of consumer products are other probably significant resources of boron that could cause a risk to the every one above a certain concentration level (ATSDR., 2010; Akram et al., 2011). Boron has 13 known isotopes of boron, the shortest-resided isotope is ${ }^{7} \mathrm{~B}$ which decays through proton emission and alpha decay, it has a 50\%-life of $3.5 \times 10^{-22} \mathrm{sec}$. probably the most steady isotopes are ${ }^{11} \mathrm{~B}(80.2 \%)$ and ${ }^{10} \mathrm{~B}(19.8 \%)$ (O’Neil et al., 2001; WHO., 1998). The major aims of this study are to estimate the boron concentrations in soil samples collected from Al-Khlaa and Al-Masharah areas of Maysan Province and provides the data which can serve as a basis for the determination of changes in the near future.

\section{MATERIALS AND METHODS}

\section{Experimental method}

The study area: The area under study (Al-Khlaa and Al-Masharah areas) are located in the Southeastern part of Maysan Province in Iraq Fig. 1. The Al-Khlaa area falls between latitudes $31^{\circ} 38^{\prime} .0^{\prime \prime} \mathrm{N}-31^{\circ} 42^{\prime} .00^{\prime \prime} \mathrm{N}$ and between longitudes $47^{\circ} 16^{\prime} .0^{\prime \prime} \mathrm{E}-47^{\circ} 20^{\prime} .0^{\prime \prime} \mathrm{E}$ and Al-Masharah area falls between latitudes $31^{\circ} 45^{\prime} .0^{\prime \prime} \mathrm{N}-31^{\circ} 51^{\prime} .00^{\prime \prime} \mathrm{N}$ and between longitudes $47^{\circ} 21^{\prime} .0^{\prime \prime} \mathrm{E}-47^{\circ} 30^{\prime} .0^{\prime \prime} \mathrm{E}$. The study areas are very important in Mays an govern 


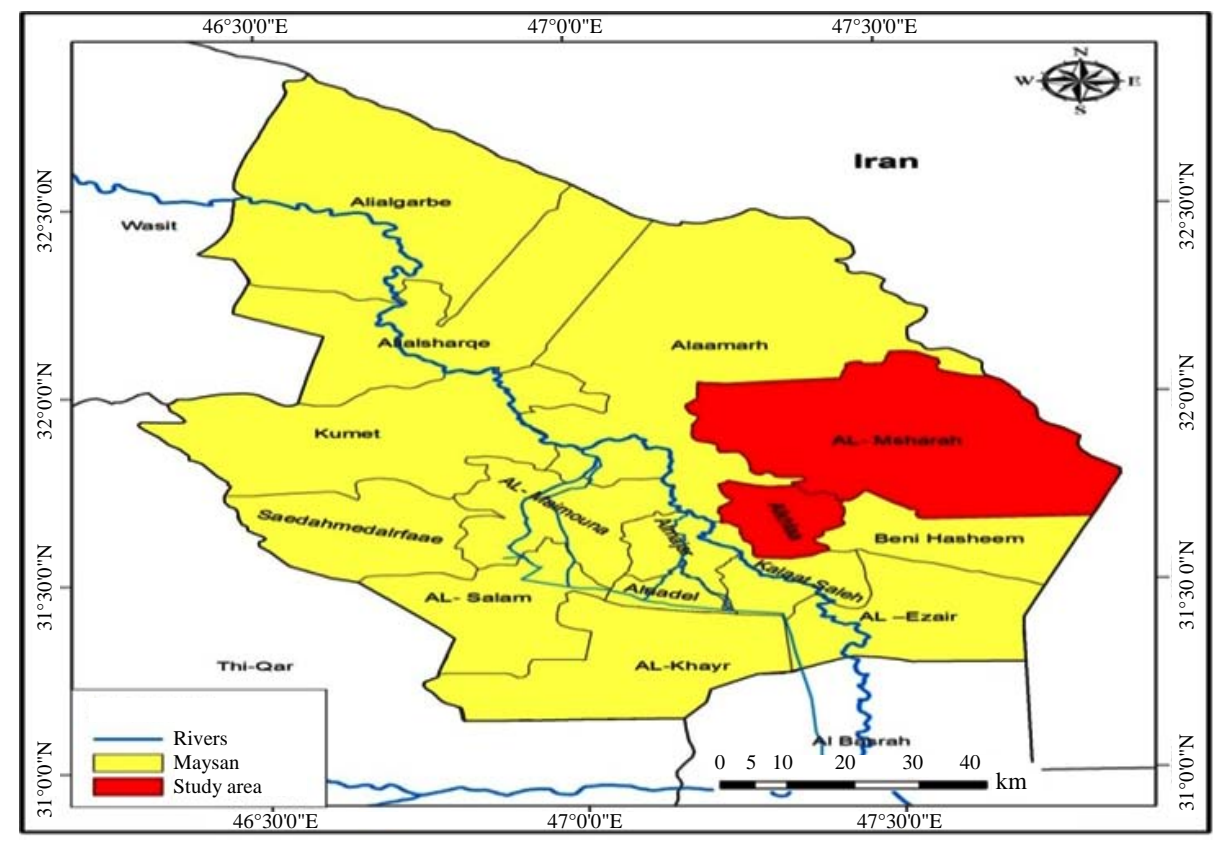

Fig. 1: Geological map of the study area

orate because of the good quality of the soil in these two regions which helps to grow grain, especially, wheat and barley and the cultivation of vegetables of all kinds. The residents in Al-Khlaa and Al-Masharah areas depends on crops as their food sources. The above causes make it is necessary for baseline study such as this to determine the basic boron levels which will serve as reference data for future studies.

Collection of samples and preparation: In the present research, a total of forty soil samples were collected from Alkhlaa area of (Alnahda, Alqadisiyah, Alsaray, Alsadreen, Aldhaleema, Albhathia, Alfouadia, Alqassemah, Ummward, Almaneaiah, Ibnsinaa), Albatool, Sayed Sefih, Alhussienieh, first Shuwailat, second Shuwailat, Alaatmad, Hamida, Gaza, Altali' ah and Al-Masharah area of Alrasala AlMohammediyah, (Alhassan Alaskari, Alsadr, Alkhaleej, Alzahraa, Almoualimin, Azoudeh, Shatt Alamai, Mtaavia, Alsudan, Aljadied, Alabouss, Aljadil, Alkhwait, Almlfod, Umm Aldairi, Alamode, Almasub, AlKhurair, Alkareemia) in Maysan Province. Twenty samples each were collected from Alkhlaa area, twenty samples from Al-Masharah area. The soil samples were collected at $0-5 \mathrm{~cm}$ depth level and the sites from where the samples were collected were given a unique code and noted with its GPS coordinate taken with a handheld GPS device as shown in Fig. 2 and 3. The soil samples were collected in plastic containers. The sample containers were then labeled and taken to the laboratory for analysis. Soil samples are air dried at $80^{\circ} \mathrm{C}$ for $2 \mathrm{~h}$ and any clods and crumbs are removed, crushed and homogenized to pass through a $75 \mu \mathrm{m}$ mesh sieve and stored in plastic container until analysis (Begy et al., 2013). These samples were analysis for boron concentrations using a ICP-OES Inductively Coupled Plasma-Optical Emission Spectrometry method (Boumans, 1987). Inductively Coupled Plasma-Optical Emission Spectrometry (ICP-OES) is a powerful tool for determination of metals in a variety of different sample matrices. With this technique, liquid samples are injected into a Radio Frequency (RF) induced argon plasma using one of a variety of nebulizers or sample introduction techniques. The sample mist reaching the plasma is quickly dried, vaporized and energized through collisional excitation at high temperature. The atomic emission emanating from the plasma is viewed in either a radial or axial configuration, collected with a lens or mirror and imaged on to the entrance slit of a wavelength selection device. Single element measurements can be performed cost-effectively with a simple Monochromator Photomultiplier Tube (PMT) combination and simultaneous multielement determinations are performed for up to 70 elements with the combination of a polychromeator and an 


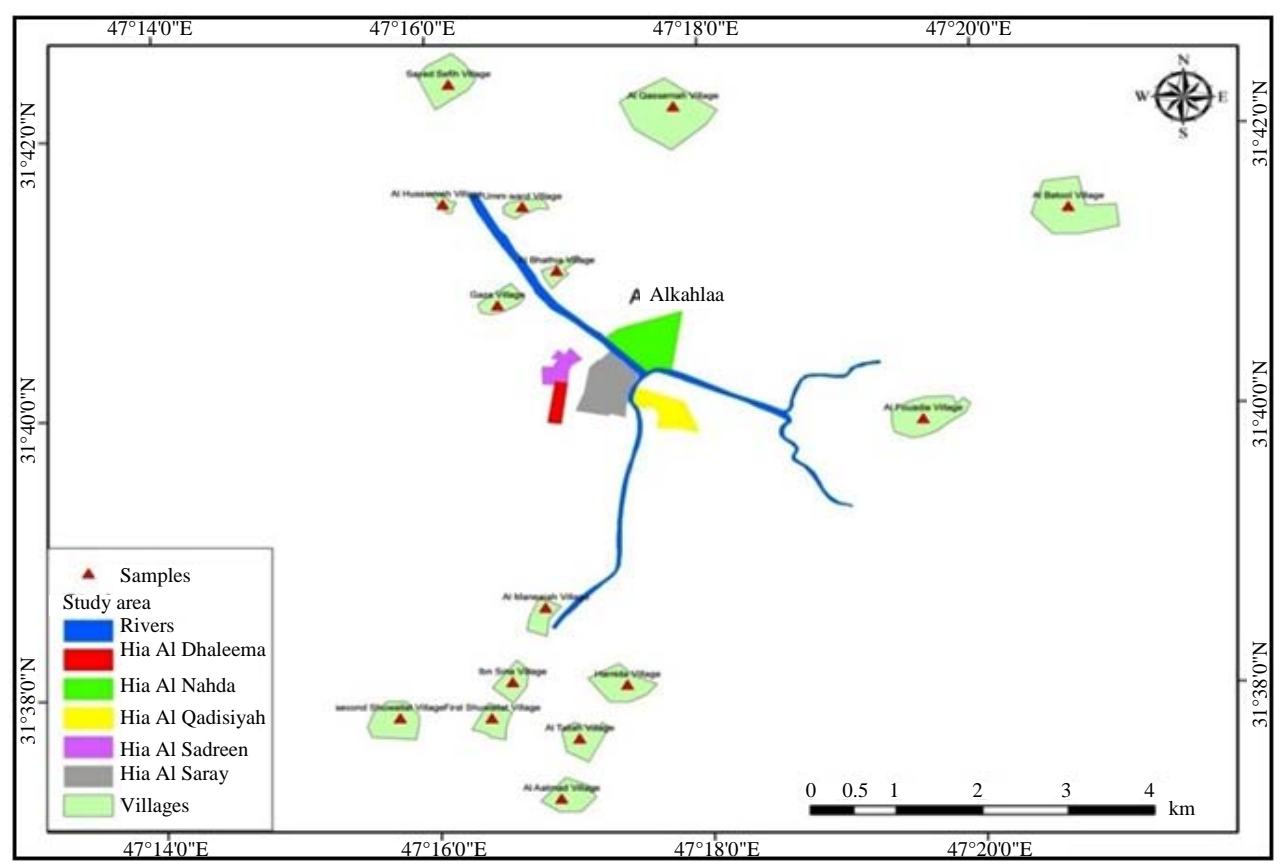

Fig. 2: Geological map of Al-Khlaa area showing locations of soil samples

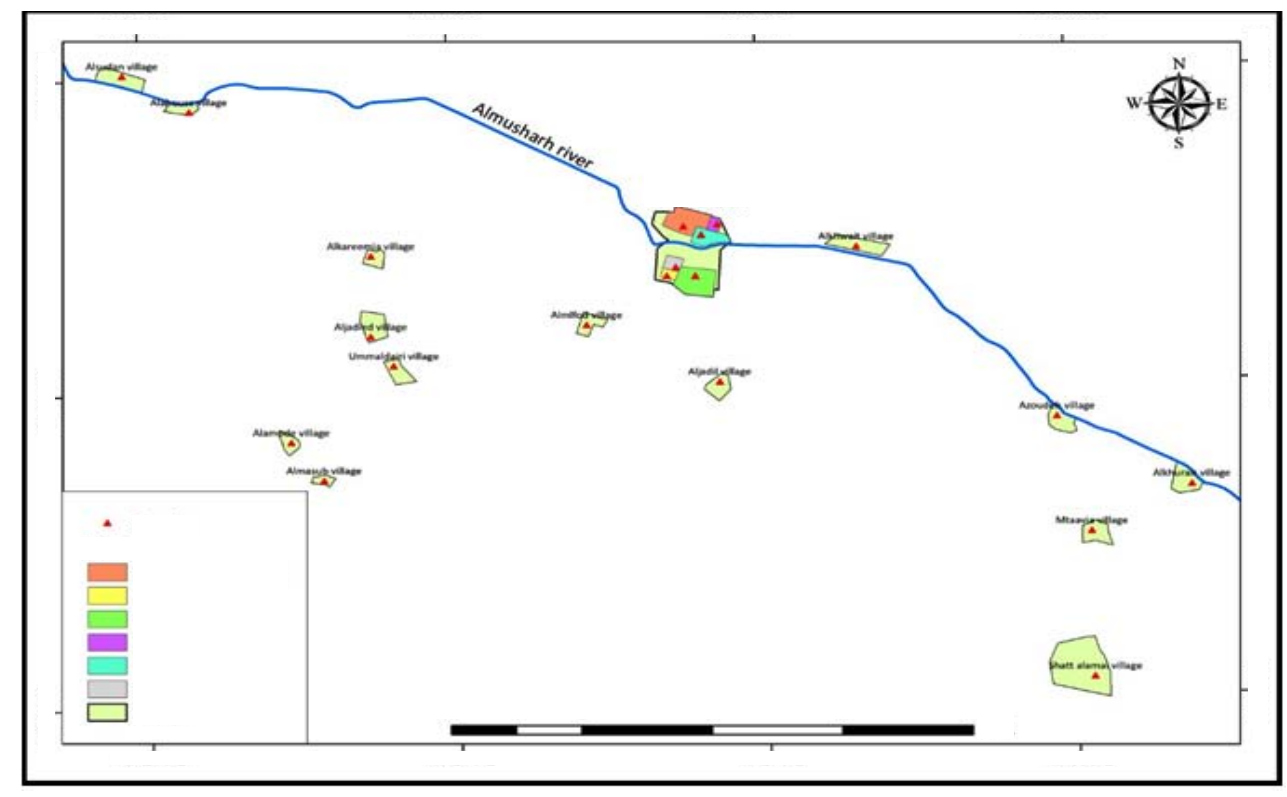

Fig. 3: Geological map of Al-Masharah area showing locations of soil samples

array detector. The analytical performance of such systems is competitive with most other inorganic analysis techniques, especially with regards to sample throughput and sensitivity.

The system equipment: The measuring of boron concentration in soil samples were done using the Inductively Coupled Plasma-Optical Emission
Spectrometry (ICP-OES) at the laboratories Tehran Islamic, Republic of Iran. The spectrometer used in the experiments is VISITA-PRO and equipped by varian Model 735-ES. Measurement conditions were adjusted to power of $1.15 \mathrm{~kW}$, plasma flow $15 \mathrm{mLmin}^{-1}$, Nebulizer flow $0.75 \mathrm{mLmin}^{-1}$, uptake delay $25 \mathrm{sec}$, pump rate $15 \mathrm{mLmin}^{-1}$. 
J. Eng. Applied Sci., 14 (Special Issue 6): 9523-9528, 2019

Table 1: Boron concentrations in the soil samples of Al-Khlaa area

\begin{tabular}{|c|c|c|c|c|}
\hline Code of soil samples & Sample location & Geographical & Location & Boron concentration (ppm) \\
\hline S1 & Alnahda & $31^{\circ} 40^{\prime} 17.1^{\prime \prime} \mathrm{N}$ & $47^{\circ} 16^{\prime} 56.5^{\prime \prime} \mathrm{E}$ & 0.91 \\
\hline S2 & Alqadisiyah & $31^{\circ} 40^{\prime} 08.6^{\prime \prime} \mathrm{N}$ & $47^{\circ} 17^{\prime} 34.2^{\prime \prime} \mathrm{E}$ & 4.55 \\
\hline S3 & Alsaray & $31^{\circ} 40^{\prime} 13.3^{\prime \prime} \mathrm{N}$ & $47^{\circ} 17^{\prime} 22.6^{\prime \prime} \mathrm{E}$ & 1.03 \\
\hline S4 & Alsadreen & $31^{\circ} 40^{\prime} 28.6^{\prime \prime} \mathrm{N}$ & $47^{\circ} 16^{\prime} 57.3^{\prime \prime} \mathrm{E}$ & 2.21 \\
\hline S5 & Aldhaleema & $31^{\circ} 40^{\prime} 04.6^{\prime \prime} \mathrm{N}$ & $47^{\circ} 16^{\prime} 55.4^{\prime \prime} \mathrm{E}$ & 1.28 \\
\hline S6 & Albhathia & $31^{\circ} 41^{\prime} 43.3^{\prime \prime} \mathrm{N}$ & $47^{\circ} 16^{\prime} 20.3^{\prime \prime} \mathrm{E}$ & 4.54 \\
\hline S7 & Alfouadia & $31^{\circ} 41^{\prime} 27.1^{\prime \prime} \mathrm{N}$ & $47^{\circ} 16^{\prime} 30.1^{\prime \prime} \mathrm{E}$ & 4.13 \\
\hline S8 & Alqassemah & $31^{\circ} 45^{\prime} 47.8^{\prime \prime} \mathrm{N}$ & $47^{\circ} 15^{\prime} 32.5^{\prime \prime} \mathrm{E}$ & 2.32 \\
\hline S9 & wardUmm & $31^{\circ} 43^{\prime} 47.3^{\prime \prime} \mathrm{N}$ & $47^{\circ} 14^{\prime} 05.8^{\prime \prime} \mathrm{E}$ & 0.89 \\
\hline S10 & Almaneaiah & $31^{\circ} 37^{\prime} 34.8^{\prime \prime} \mathrm{N}$ & $47^{\circ} 17^{\prime} 07.7^{\prime \prime} \mathrm{E}$ & 4.40 \\
\hline S11 & Ibn sinaa & $31^{\circ} 35^{\prime} 07.5^{\prime \prime} \mathrm{N}$ & $47^{\circ} 17^{\prime} 32.3^{\prime \prime} \mathrm{E}$ & 0.71 \\
\hline S12 & Albatool & $31^{\circ} 40^{\prime} 58.1^{\prime \prime} \mathrm{N}$ & $47^{\circ} 16^{\prime} 50.8^{\prime \prime} \mathrm{E}$ & 2.36 \\
\hline $\mathrm{S} 13$ & Sayed Sefih & $31^{\circ} 45^{\prime} 10.4^{\prime \prime} \mathrm{N}$ & $47^{\circ} 13^{\prime} 27.1^{\prime \prime} \mathrm{E}$ & 2.21 \\
\hline S14 & Alhussienieh & $31^{\circ} 44^{\prime} 58.9^{\prime \prime} \mathrm{N}$ & $47^{\circ} 13^{\prime} 31.6^{\prime \prime} \mathrm{E}$ & 1.80 \\
\hline S15 & First Shuwailat & $31^{\circ} 34^{\prime} 15.4^{\prime \prime} \mathrm{N}$ & $47^{\circ} 17^{\prime} 33.3^{\prime \prime} \mathrm{E}$ & 1.63 \\
\hline S16 & Second Shuwailat & $31^{\circ} 34^{\prime} 55.8^{\prime \prime} \mathrm{N}$ & $47^{\circ} 16^{\prime} 59.2^{\prime \prime} \mathrm{E}$ & 3.33 \\
\hline S17 & Alaatmad & $31^{\circ} 37^{\prime} 47.9^{\prime \prime} \mathrm{N}$ & $47^{\circ} 16^{\prime} 51.8^{\prime \prime} \mathrm{E}$ & 4.31 \\
\hline S18 & Hamida & $31^{\circ} 39^{\prime} 07.4^{\prime \prime} \mathrm{N}$ & $47^{\circ} 17^{\prime} 29.5^{\prime \prime} \mathrm{E}$ & 4.21 \\
\hline S19 & Gaza & $31^{\circ} 42^{\prime} 32.4^{\prime \prime} \mathrm{N}$ & $47^{\circ} 14^{\prime} 52.4^{\prime \prime} \mathrm{E}$ & 5.12 \\
\hline S20 & Altali'ah & $31^{\circ} 38^{\prime} 26.7^{\prime \prime} \mathrm{N}$ & $47^{\circ} 16^{\prime} 39.5^{\prime \prime} \mathrm{E}$ & 3.33 \\
\hline
\end{tabular}

*Detection limit for Boron $=0.1$ ppm, Mean value 2.76 \pm 1.47 , ATSDR (1992) limit 30

Table 2: Boron concentrations in the soil samples of Al-Masharah area

\begin{tabular}{|c|c|c|c|c|}
\hline Code of soil samples & Sample location & Geographical & Location & Boron concentration (ppm) \\
\hline S1 & Alrasala Almohammediyah & $31^{\circ} 49^{\prime} 24.9^{\prime \prime} \mathrm{N}$ & $47^{\circ} 26^{\prime} 30.6^{\prime \prime} \mathrm{E}$ & 1.34 \\
\hline S2 & Alhassan Alaskari & $31^{\circ} 49^{\prime} 28.1^{\prime \prime} \mathrm{N}$ & $47^{\circ} 26^{\prime} 16.0^{\prime \prime} \mathrm{E}$ & 2.26 \\
\hline S3 & Alsadr & $31^{\circ} 49^{\prime} 24.9^{\prime \prime} \mathrm{N}$ & $47^{\circ} 26^{\prime} 08.9^{\prime \prime} \mathrm{E}$ & 1.81 \\
\hline S4 & Alkhaleej & $31^{\circ} 49^{\prime} 11.1^{\prime \prime} \mathrm{N}$ & $47^{\circ} 26^{\prime} 10.6^{\prime \prime} \mathrm{E}$ & 1.81 \\
\hline S5 & Alzahraa & $31^{\circ} 49^{\prime} 03.6^{\prime \prime} \mathrm{N}$ & $47^{\circ} 26^{\prime} 11.0^{\prime \prime} \mathrm{E}$ & 0.69 \\
\hline S6 & Almoualimin & $31^{\circ} 49^{\prime} 03.3^{\prime \prime} \mathrm{N}$ & $47^{\circ} 26^{\prime} 13.1^{\prime \prime} \mathrm{E}$ & 4.74 \\
\hline S7 & Azoudeh & $31^{\circ} 48^{\prime} 34.2^{\prime \prime} \mathrm{N}$ & $47^{\circ} 28^{\prime} 56.4^{\prime \prime} \mathrm{E}$ & 1.60 \\
\hline S8 & Shatt Alamai & $31^{\circ} 45^{\prime} 48.4^{\prime \prime} \mathrm{N}$ & $47^{\circ} 30^{\prime} 05.6^{\prime \prime} \mathrm{E}$ & 3.36 \\
\hline S9 & Mtaavia & $31^{\circ} 47^{\prime} 45.9^{\prime \prime} \mathrm{N}$ & $47^{\circ} 27^{\prime} 56.2^{\prime \prime} \mathrm{E}$ & 0.57 \\
\hline S10 & Alsudan & $31^{\circ} 51^{\prime} 02.4^{\prime \prime} \mathrm{N}$ & $47^{\circ} 20^{\prime} 50.0^{\prime \prime} \mathrm{E}$ & 4.58 \\
\hline S11 & Aljadied & $31^{\circ} 48^{\prime} 27.4^{\prime \prime} \mathrm{N}$ & $47^{\circ} 21^{\prime} 05.8^{\prime \prime} \mathrm{E}$ & 2.06 \\
\hline S12 & Alabouss & $31^{\circ} 50^{\prime} 54.1^{\prime \prime} \mathrm{N}$ & $47^{\circ} 21^{\prime} 15.6^{\prime \prime} \mathrm{E}$ & 0.93 \\
\hline S13 & Aljadil & $31^{\circ} 47^{\prime} 47.6^{\prime \prime} \mathrm{N}$ & $47^{\circ} 26^{\prime} 25.9^{\prime \prime} \mathrm{E}$ & 0.83 \\
\hline S14 & Alkhwait & $31^{\circ} 49^{\prime} 11.7^{\prime \prime} \mathrm{N}$ & $47^{\circ} 27^{\prime} 59.2^{\prime \prime} \mathrm{E}$ & 1.03 \\
\hline S15 & Almlfod & $31^{\circ} 48^{\prime} 19.5^{\prime \prime} \mathrm{N}$ & $47^{\circ} 25^{\prime} 04.1^{\prime \prime} \mathrm{E}$ & 0.56 \\
\hline S16 & Umm Aldairi & $31^{\circ} 48^{\prime} 07.4^{\prime \prime} \mathrm{N}$ & $47^{\circ} 22^{\prime} 53.4^{\prime \prime} \mathrm{E}$ & 0.47 \\
\hline S17 & Alamode & $31^{\circ} 47^{\prime} 30.4^{\prime \prime} \mathrm{N}$ & $47^{\circ} 22^{\prime} 28.9^{\prime \prime} \mathrm{E}$ & 0.32 \\
\hline S18 & Almasub & $31^{\circ} 46^{\prime} 54.0^{\prime \prime} \mathrm{N}$ & $47^{\circ} 22^{\prime} 27.1^{\prime \prime} \mathrm{E}$ & 0.64 \\
\hline S19 & Alkhurair & $31^{\circ} 47^{\prime} 14.1^{\prime \prime} \mathrm{N}$ & $47^{\circ} 30^{\prime} 51.1^{\prime \prime} \mathrm{E}$ & 0.65 \\
\hline S20 & Alkareemia & $31^{\circ} 49^{\prime} 10.5^{\prime \prime} \mathrm{N}$ & $47^{\circ} 23^{\prime} 04.4^{\prime \prime} \mathrm{E}$ & 0.53 \\
\hline
\end{tabular}

\section{RESULTS AND DISCUSSION}

The results of boron concentrations measured in all soil samples, collected from different locations of Al-Khlaa and Al-Masharah areas in Maysan Province are given in Table 1 and 2.

The boron concentrations in soil samples ranged from $0.71 \mathrm{ppm}$ (S11) (Ibn Sinaa) to $5.12 \mathrm{ppm}$ (S19) (Gaza) with a mean of $2.76 \mathrm{ppm}$ for Alkhlaa area Table 1and Fig. 4 and from $0.32 \mathrm{ppm}$ (S17) (Alamode) to $4.74 \mathrm{ppm}$ (S6 (Almoualimin) with a mean of $1.53 \mathrm{ppm}$ for Al-Masharah area Table 2 and Fig. 5. The study results showed that all the values of the boron concentrations in all soil samples for Al-Khlaa and Al-Masharah areas were below the ATSDR recommended value of $30 \mathrm{ppm}$ for Earth soil (ATSDR., 1992).

The study results showed that all the values of the boron concentrations in all soil samples for Al-Khlaa and Al-Masharah areas were below the ATSDR recommended value of $30 \mathrm{ppm}$ for Earth soil (ATSDR., 1992). 


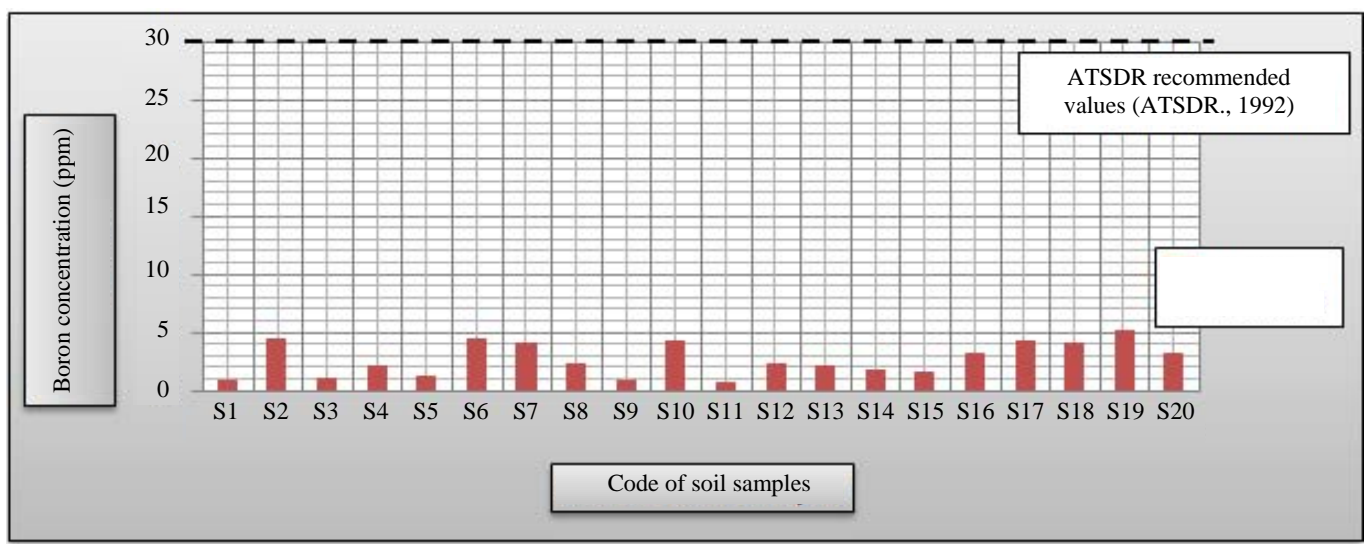

Fig. 4: Boron concentration in soil samples of Al-Khlaa area

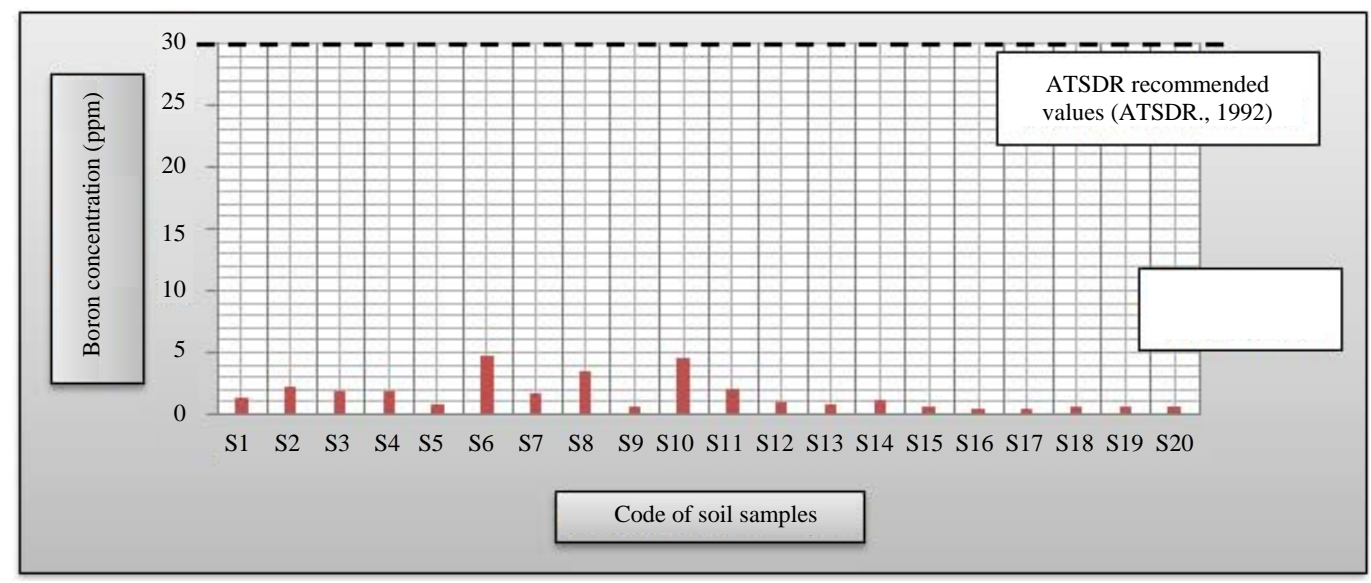

Fig. 2: Boron concentration in soil samples of Al-Masharah area

\section{CONCLUSION}

In this study, boron concentration in soil samples collected from Al-Khlaa and Al-Masharah areasin Maysan Province were determined using Inductively Coupled Plasma-Optical Emission Spectrometry (ICP-OES).

The final results obtained indicated that the boron concentrations in soil samples of the study area were overall below the recommended value by Agency for Toxic Substances and Disease Registry (ATSDR) which equal to $30 \mathrm{ppm}$ for the Earth soil (ATSDR., 1992). Therefore, it can be concluded that the soil samples of the area under the study, i.e., Al-Khlaa and Al-Masharah areas are free from contamination levels of boron and these soil of areas can be used for agriculture without impose any serious threat to the health of locals. Furthermore, the results obtained from this study baselines for these areas and could help to create a public awareness about boron concentration in the soil and its impact on human health.

\section{REFERENCES}

ATSDR., 1992. Toxicological profile for Boron. Agency for Toxic Substances and Disease Registry, Atlanta, Georgia, USA.

ATSDR., 2010. Toxicological profile for Boron. Agency for Toxic Substances and Disease Registry, Atlanta, Georgia, USA. https://www.atsdr.cdc.gov/toxprofiles/ tp26.pdf

Akram, M., Matiullah, A. Iqbal, S.N. Husaini and F. Malik, 2011. Determination of boron contents in water samples collected from the Neelum Valley, Azad Kashmir, Pakistan. Biol. Trace Elem. Res., 139: 287-295. 
Akram, M., N.U. Khattak, A.A. Qureshi, A. Iqbal and K. Ullah et al., 2004. Neutron induced radiography in the determination of boron in drinking water. J. Radioanal. Nucl. Chem., 261: 429-435.

Begy, R.C., H. Simon and C. Cosma, 2013. Radiological assessment of stream sediments between Baita-Plai and Beius. Rom. J. Phys., 58: S22-S28.

Boumans, P.W.J.M., 1987. Inductively Coupled Plasma-Emission Spectroscopy, Part 1: Methodology, Instrumentation and Performance. Wiley Publishing Company, Hoboken, New Jersey, USA., ISBN:978-0-471-09686-3, Pages: 608.

Fleifi, S.S. and T.M. Salman, 2016. The measurements of boron concentration in water samples of the rivers in Basrah Governorates using SSNTDs techniques. Adv. Phys. Theor. Appl., 53: 29-34.
O'Neil, M.J., S. Budavari, A. Smith and P.E. Heckelman, 2001. The Merck Index: An Encyclopedia of Chemicals, Drugs and Biologicals. 13th Edn., Wiley, Hoboken, New Jersey, USA., ISBN:9780911910131, Pages: 2564.

Salman, T.M. and S.S. Fleifil, 2015. The measurements of boron concentration rate in soil samples of Basrah Governorate (in Iraq) using ICP/OES Techniques. Intl. J. Emerging Technol. Comput. Appl. Sci., 14: $157-162$.

WHO., 1998. Guidelines for Drinking-Water Quality: Health Criteria and Other Supporting Information. 2nd Edn.,/Vol. 2, World Health Organization, Geneva, Switzerland, Pages: 294.

WHO., 2004. Guidelines for Drinking-Water Quality. 3rd Edn.,/Vol 1, World Health Organization, Geneva, Switzerland, ISBN:92-4154638-7, Pages: 515. 